\title{
SUSCEPTIBILITY TO HERBIVORES DEPENDS ON RECENT HISTORY OF BOTH THE PLANT AND ANIMAL ${ }^{1}$
}

\author{
Greg CRONIN ${ }^{2}$ AND MARK E. HAY ${ }^{3}$ \\ University of North Carolina at Chapel Hill, Institute of Marine Sciences, Morehead City, North Carolina 28557 USA
}

\begin{abstract}
Physical stress to seaweeds and hunger stress of herbivores can influence the outcome of chemically mediated seaweed-herbivore interactions. The unpalatable brown seaweed Dictyota ciliolata produces the diterpenoid secondary metabolites pachydictyol A, dictyol B acetate, and dictyodial. At natural concentrations, pachydictyol A deterred the sea urchin Arbacia punctulata but did not inhibit feeding by the pinfish Lagodon rhomboides or the amphipod Ampithoe longimana until concentrations were 2.5-5 times natural levels. Dictyol B acetate deterred the urchin, amphipod, and pinfish at, or far below, natural concentrations. Dictyodial was too unstable to assay directly, but indirect experiments suggested that natural concentrations deterred the urchin, but not the pinfish or amphipod. Mild desiccation of $D$. ciliolata reduced concentrations of the different secondary metabolites by 7-38\% and plants became 2.6-3.4 times more susceptible to urchin and amphipod grazing. The combined concentrations of pachydictyol A and dictyol B acetate found in undesiccated Dictyota ciliolata deterred feeding by urchins, but this deterrent effect was lost at concentrations found in the desiccated plants. Desiccated and undesiccated plants did not differ in nutritive value (as measured by protein and total $\mathrm{N}$ content) or toughness. Thus, desiccated plants became more palatable because chemical defenses were lost, not because nutritive value was increased.

The stress of near-surface ultraviolet radiation also caused significant physiological changes in Dictyota ciliolata. UV-exposed blades bleached, senesced, and grew $84 \%$ less than blades protected from UV radiation. Tissue loss and minimal growth of UV-stressed plants constrained our sample sizes, but the limited assays that could be run suggested that UV stress may lower chemical defenses and increase plant susceptibility to herbivores.

Because many previous investigations of herbivore feeding patterns used animals that had been starved for days before an assay, we tested the effects of this commonly used procedure on feeding discrimination. Recently fed urchins always avoided food containing natural concentrations of pachydictyol A during separate feeding trials performed on each of four consecutive days. In contrast, urchins deprived of food for $3 \mathrm{~d}$ before this assay did not avoid the treated food on days 1 and 2 of feeding trials, but did avoid it on days 3 and 4 after their hunger was reduced by feeding during days 1 and 2 . If we had used only starved urchins (a common procedure in previous investigations), we could have concluded, with apparent justification, that urchins were unaffected by pachydictyol A (if the assays were run for only 1-2 d) or that they needed $2 \mathrm{~d}$ of exposure to the compound in order to learn to avoid it. Both of these conclusions would have been incorrect.
\end{abstract}

Key words: Ampithoe; Arbacia; chemical defense; desiccation; Dictyota; feeding behavior; Lagodon; plant-herbivore interaction; stress-induced changes; UV radiation.

\section{INTRODUCTION}

Seaweeds and marine herbivores live in constantly changing environments where benign and stressful periods are interspersed. Effects of these periodic stresses on seaweed-herbivore interactions are relatively unstudied, but it is clear that seaweed-herbivore interactions depend on both plant characteristics (Lubchenco and Gaines 1981, Hay and Fenical 1988, Duffy and Hay 1990, Hay and Steinberg 1992) and herbivore behavior and physiology (Lawrence 1975, Hawkins and Hartnoll 1983, Horn 1989). A few marine studies have

\footnotetext{
${ }^{1}$ Manuscript received 19 December 1994; revised and accepted 17 October 1995.

${ }^{2}$ Present address: Department of Biological Sciences, University of Notre Dame, Notre Dame, Indiana 46556 USA.

${ }^{3}$ Send reprint requests to this author.
}

investigated how recent physical (e.g., desiccation) or biological (e.g., grazing) history affects seaweed susceptibility to herbivores. These studies have sometimes (Van Alstyne 1988, Renaud et al. 1990, Yates and Peckol 1993, Cronin and Hay, in press), but not always (Paul 1992, Steinberg 1992, 1994, 1995), found that seaweed susceptibility to herbivores can be altered by these stresses. Possible mechanisms affecting these changes have been proposed (Van Alstyne 1988, Renaud et al. 1990, Yates and Peckol 1993, Cronin and Hay, in press), but rarely tested directly. In this study, we investigate how the stresses of desiccation and UV radiation affect seaweed chemical defenses and susceptibility to herbivores, and how mild food deprivation alters sea urchin feeding on a chemically defended diet. 
Interactive effects of stresses on seaweeds range from one stress ameliorating the effects of another, to two stresses acting additively or synergistically to negatively affect an alga. Examples of stresses that interact to ameliorate their overall effect include (1) mitigation of temperature stress by desiccation (Gessner 1970) and (2) reduction of herbivory due to desiccation (Renaud et al. 1990), interspecific competition (Hay 1986), or low nutrient levels (Yates and Peckol 1993). Stresses that act additively or synergistically to cause a greater detrimental effect include (1) increased susceptibility to herbivores due to desiccation (Renaud et al. 1990) and (2) increased plant loss to wave action because kelp stipes rip at small grazing scars (Koehl and Wainwright 1977). In the latter example, it could be argued that neither the small grazing scars nor wave energy alone are very stressful, but in combination they have a large negative impact on seaweed survivorship.

The only previous study that assessed how physical stresses affected seaweed susceptibility to herbivores found that desiccation could either increase or decrease seaweed susceptibility to sea urchin grazing, depending on the initial palatability of the species being investigated (Renaud et al. 1990). The current study is a first attempt to experimentally address the interactive effects of stresses to seaweeds and to herbivores, and how they affect seaweed chemical defenses and herbivore responses to these defenses. We use the chemically defended brown alga Dictyota ciliolata to address the following questions: (1) What is the relative palatability of $D$. ciliolata to a sympatric sea urchin, fish, and amphipod? (2) How do secondary metabolites produced by $D$. ciliolata affect feeding by these herbivores? (3) How do physical stresses (i.e., desiccation and UV radiation) affect the physiology, chemical defenses, tissue nutritive value, and toughness of the seaweeds, and do these traits alter the resistance of $D$. ciliolata to herbivores? (4) How does hunger stress influence the response of a sea urchin to a defensive metabolite produced by $D$. ciliolata?

\section{Methods}

\section{The organisms}

All organisms used in this study co-occur on the rock jetty at Radio Island, North Carolina $\left(34^{\circ} 34^{\prime} \mathrm{N}, 76^{\circ} 40^{\prime}\right.$ W; see Hay 1986, Pfister and Hay 1988 for a description), which is similar to many other hard substrate communities in the South Atlantic Bight (Hay and Sutherland 1988). Turbid water at this site limits $D$. ciliolata and most other algae to depths of $<3 \mathrm{~m}$. Because shallow plants are periodically exposed to atmospheric conditions during low tides, it is ecologically meaningful to assess the effects of desiccation and UV radiation on $D$. ciliolata and the cascading effects of these stresses on the plant's chemical defenses and interactions with herbivores.

Most organisms were collected from Radio Island
Jetty or nearby seagrass beds and sand flats. Because densities of Ampithoe longimana are highly variable in the field (Duffy and Hay 1991, Cronin and Hay, in press), this amphipod was initially collected from $D$. menstrualis in seagrass beds and then cultured in six 20-L flow-through mesocosms on a mixed diet of freshly collected algae. This allowed a predictable supply of amphipods.

To avoid unnaturally high levels of feeding motivation during the feeding assays, all herbivores were fed prior to assays (except for experiments designed to determine the effects of starvation on the feeding behavior of sea urchins). The pinfish Lagodon rhomboides was fed commercial food pellets every morning with feeding assays commencing in the early afternoon. The sea urchin Arbacia punctulata was fed fresh, palatable, nonassay algae (Gracilaria tikvahiae, Agardhiella ramosissima, or Codium fragile) until shortly before the assay. Ampithoe was removed from culture tanks that contained several food plants just prior to being used in feeding assays.

Dictyota ciliolata produces three diterpenoid secondary metabolites: pachydictyol A, dictyol B acetate, and dictyodial (Cronin et al. 1995). Pachydictyol A occurs at $0.006-0.02 \%$ of algal wet mass $(=\mathrm{WM})$ or $0.05-0.2 \%$ of algal dry mass (=DM). Dictyol B acetate occurs at $0.05-0.08 \%$ WM $(0.4-0.7 \%$ DM). True concentrations of dictyodial are not known because it is unstable; relative concentrations can, however, be measured (Cronin et al. 1995). When coated onto the surface of palatable plants, pachydictyol A (1) deterred feeding by the spottail pinfish Diplodus holbrooki at $0.5 \% \mathrm{DM}$ and the pinfish Lagodon rhomboides at $1.0 \%$ DM, (2) had no effect on the sea urchin Arbacia punctulata at $1.3 \% \mathrm{DM}$, and (3) did not deter, but at some concentrations stimulated, feeding by the amphipod Ampithoe longimana at $0.1-1.0 \%$ DM (Hay et al. 1987a, 1988). Dictyol B acetate at 1.0\% DM deterred feeding by Caribbean reef fishes in the field (Hay et al. 1990). At $0.5 \%$ DM, it deterred feeding by the temperate amphipods Ampithoe valida and Gammarus mucronatus, but did not affect feeding by A. longimana (Duffy and Hay 1994). Effects of dictyol B acetate on feeding by temperate fishes and urchins are unknown, as are effects of dictyodial on any herbivore.

\section{Palatability of Dictyota}

The palatability of Dictyota ciliolata was first assessed by offering the pinfish Lagodon rhomboides and the sea urchin Arbacia punctulata a choice between $D$. ciliolata and the palatable (Hay et al. 1987a, 1988) red alga Hypnea musciformis. Assay algae were spun for $\approx 10 \mathrm{~s}$ in a salad spinner to remove excess seawater, weighed to the nearest milligram, and offered to an individual herbivore held in a 1.8 - $\mathrm{L}$ tub with flowthrough seawater. Each herbivore was offered a choice between equivalent-sized pieces of each alga (spun $\mathrm{WM}=482 \pm 15 \mathrm{mg}$ per piece; mean $\pm 1 \mathrm{SE}$ ). An 
individual plant was used in only one replicate. Paired plant pieces (i.e., from the same individual plant) were also set up without herbivores to control for autogenic changes in wet mass (Peterson and Renaud 1989, Renaud et al. 1990). After $21 \mathrm{~h}$, the plants were reweighed as before and the amount consumed was calculated using the equation $\left[\left(H_{0} \times C_{f} / C_{0}\right)-H_{f}\right]$; where $H_{0}$ and $H_{f}$ were the initial and final wet masses, respectively, of the algal piece exposed to herbivory, and $C_{0}$ and $C_{f}$ were the initial and final masses of the paired control for autogenic changes. These data were analyzed with a paired-sample $t$ test (paired by individual herbivore). Directed $P$ values $\left(P_{\mathrm{drr}}\right)$ with $\gamma / \alpha=0.8$ as suggested by Rice and Gaines (1994) were calculated because we predicted that $D$. ciliolata would be less palatable than $H$. musciformis as the former co-exists with high numbers of herbivorous fishes and urchins and the latter does not.

The palatability of Dictyota ciliolata relative to its congener $D$. menstrualis also was determined for the sea urchin and the amphipod (pinfish will not feed on either Dictyota species). Dictyota menstrualis is known to be a low preference prey of the sea urchin, but the amphipod $A$. longimana prefers $D$. menstrualis over many other seaweeds (called $D$. dichotoma in Hay et al. 1987a). Because urchins often shred algae and the two species of Dictyota are too similar to confidently identify shredded pieces to species, a no-choice assay was performed so the two congeners would not need to be placed in the same tub. One gram ( $\pm 20 \mathrm{mg}$ ) spun wet mass of each plant was placed in a flow-through 1.8-L plastic tub with a randomly assigned urchin, and urchins were allowed to feed for $3 \mathrm{~d}$. A paired $1-\mathrm{g}$ piece of each plant was placed in a similar tub without an urchin to control for autogenic changes in mass.

For assays with the amphipod, upper portions of plants $(N=27$ for each plant species) were blotted with a paper towel to remove excess seawater and weighed to the nearest milligram. The two species were distinguished by sewing threads of slightly different lengths through each piece of alga. Individual amphipods were offered a choice between pieces of $D$. ciliolata and $D$. menstrualis ( $40 \pm 0.3 \mathrm{mg}$ per piece) in $\approx 100 \mathrm{~mL}$ of seawater for $38 \mathrm{~h}$. The position of each amphipod (i.e., on D. ciliolata, D. menstrualis, or neither alga) was recorded 0,17 , and $37 \mathrm{~h}$ into the assay. Another set of plant pieces was set up without amphipods to control for changes in algal mass not due to amphipods.

At the end of the urchin and amphipod assays the algae were reweighed as before and the amount of each plant consumed was calculated as above. Data from the no-choice urchin assay were analyzed with a two-sample $t$ test and data from the choice amphipod assay were analyzed with a paired-sample $t$ test (paired by herbivore). Two-tailed $P$ values were used because no a priori predictions were made for the similar congeneric seaweeds.

\section{Effects of secondary metabolites on herbivore feeding behavior}

Pachydictyol A and dictyol B acetate were obtained from a large collection of Dictyota ciliolata and purified as described in Cronin et al. (1995). Dictyodial could not be purified in amounts large enough to perform feeding assays because the compound is too labile. However, because dictyodial decomposes when Dictyota is freeze dried (Cronin et al. 1995), we were able to obtain an extract of Dictyota with greatly reduced amounts of dictyodial by freeze-drying half of a frozen collection of Dictyota menstrualis prior to extraction, while the remaining frozen half was extracted without freeze-drying. Dictyota menstrualis was used as a source of dictyodial instead of Dictyota ciliolata because both congeners contain similar concentrations of dictyodial but $D$. menstrualis lacks dictyol B acetate (Cronin et al. 1995), which could mask the effects of dictyodial because dictyol B acetate is such a strong feeding deterrent (Hay et al. 1990, Duffy and Hay 1994, this study). Although D. menstrualis produces the different diterpene alcohol dictyol $\mathrm{E}$, the collection we used did so at concentrations $(\approx 0.2 \% \mathrm{DM})$ that do not affect feeding by Arbacia punctulata or Ampithoe longimana (Hay et al. 1987a, Duffy and Hay 1994, Cronin and Hay, in press). The extracts from frozen vs. freezedried D. menstrualis were fractionated with Florisil chromatography in order to remove many of the nondictyol compounds and, thus, produce a-"dictyol fraction" (Cronin et al. 1995). Individual compounds in the different dictyol fractions were analyzed quantitatively by HPLC using the methods of Cronin et al. (1995).

The effects of secondary metabolites or partially purified Dictyota extracts on feeding by the pinfish, urchin, and amphipod were assessed by making an artificial food with (i.e., treatment food) or without (i.e., control food) secondary metabolites or dictyol fractions. Artificial foods were made by mixing freezedried and finely powdered green algae (Ulva for urchin assays and a 5:4:1 mixture of Ulva, Enteromorpha, and Cladophora for fish and amphipod assays because fish and amphipods did not feed well on Ulva alone) into an agar base and forming this onto fiberglass window screening material. The screen provided support and an internal uniform grid that allowed us to quantify the amount eaten by counting the squares of the screen that had been cleared of algae (see Hay et al. 1994 for detailed methods).

In each feeding assay, the herbivores were offered equal amounts of control and treated food. Data were analyzed with paired-sample $t$ tests. Directed $P$ values were used for pinfish and urchins because these herbivores treat Dictyota ciliolata as a low preference food, suggesting that these herbivores would be deterred by the secondary metabolites. Two-tailed $P$ values were used for the amphipod assays because am- 
phipods readily consume $D$. ciliolata. After an assay, we extracted uneaten artificial foods and analyzed these with thin-layer chromatography to assure that the test compound was still present in the treated food at the end of the assay.

For Arbacia punctulata and Lagodon rhomboides, compounds were initially tested at $0.023 \%$ WM (about natural concentration for pachydictyol A; $25-40 \%$ of natural concentration for dictyol $\mathrm{B}$ acetate). For Ampithoe longimana, initial assays were run at $0.058 \%$ WM $(\approx 3$ times natural concentration for pachydictyol $\mathrm{A} ; \approx 60-100 \%$ of natural concentration for dictyol $\mathrm{B}$ acetate). Concentrations were adjusted for subsequent assays in order to learn the general concentration at which compounds were deterrent. A group of herbivores was used repeatedly in a series of assays for a compound; however, the same individual herbivores were not used for more than one compound. Thus, it is possible that herbivores became sensitized from repeated exposures to compounds, but the space and time involved in housing and acclimating herbivores made it impractical to use new animals for each assay. Additionally, in the field herbivores would have the opportunity of repeated exposure to Dictyota and its defenses.

$$
\text { - }
$$

\section{Desiccation}

To assess the effects of desiccation on Dictyota ciliolata, 25 individual plants were collected subtidally from Radio Island Jetty, divided in half, and each half placed in a separate 1.8 -L plastic tub with seawater. After pouring the seawater out of the tub holding one of the halves from each plant, the plant was desiccated for $1 \mathrm{~h}$ in the shade and protected from the wind. The other plant half was used as a control and remained submerged in seawater next to its paired, desiccated half. During the 1-h-long desiccation treatment, the air temperature was $29.5^{\circ} \mathrm{C}$ and the seawater temperature of the control tubs was $31.0^{\circ} \mathrm{C}$. After desiccation, plants were allowed to recover in flow-through seawater overnight before we began measurements of plant characteristics such as thallus toughness, photosynthetic and respiration rates, resistance to grazing by Arbacia punctulata and Ampithoe longimana, secondary metabolite composition, and carbon, nitrogen, and soluble protein content.

Tissue toughness $2 \mathrm{~cm}$ below the apex was determined ( $N=25$ paired halves) by measuring the force required to puncture the thallus with an insect pin (see Duffy and Hay 1991 for methods). After $18 \mathrm{~h}$ of recovery in flowing seawater, net photosynthesis and respiration were measured by monitoring oxygen production and consumption, respectively (Littler 1979). Plants, and proper blanks, were incubated at $\approx 200$ $\mu \mathrm{mol}$ photons $\cdot \mathrm{m}^{-2} \cdot \mathrm{s}^{-1}$ for $1.7 \mathrm{~h}$ at $\approx 30^{\circ} \mathrm{C}$ under a battery of interspersed fluorescent cool white lights and grow lights to determine photosynthetic rates. The same plants were incubated in complete darkness for $5.4 \mathrm{~h}$ to determine respiration rates.

To determine the effect of desiccation on Dictyota's resistance to grazing by Ampithoe longimana, individual amphipods were offered a choice between an undesiccated and a desiccated branch (WM $=45.0 \pm 1.5$ $\mathrm{mg}$, mean $\pm 1 \mathrm{SE}$ ) from the same plant after the plants had recovered in seawater for $28 \mathrm{~h}$. Threads of slightly different lengths were sewn through the undesiccated and desiccated pieces to distinguish them. This assay ran for $36 \mathrm{~h}$. Controls for autogenic changes in mass, paired by individual plants, were set up in the same manner, but without amphipods. Because weighing errors could account for a substantial portion of the actual mass of tissue consumed by a single amphipod, we measured the surface area of tissue consumed. Pieces of algae were quickly photocopied on acetate sheets and returned to seawater. The surface area of images before and after grazing was measured with an area meter (LI-COR Model 3100, LI-COR, Lincoln, Nebraska, USA). For each half of each plant, the wet mass: surface area ratio was determined and used to calculate the wet mass of tissue consumed by amphipods. Tissue consumption was expressed as wet mass because the wet mass:surface area ratio differed between undesiccated and desiccated tissue $(6.7 \pm 0.2$ vs. $6.2 \pm 0.3$ $\mathrm{mg} / \mathrm{cm}^{2}$, respectively; $P_{\text {two-talled }}=0.042$, paired-sample $t$ test).

The effect of desiccation on the resistance of Dictyota ciliolata to grazing by Arbacia punctulata was determined in a no-choice feeding assay after the alga had recovered for $\approx 40 \mathrm{~h}$ in flowing seawater. Each piece of alga (205 $\pm 3 \mathrm{mg}$ ) was spun in a salad spinner to remove excess water, quickly weighed to the nearest milligram, and immediately placed in a 1.8 - $\mathrm{L}$ tub with one urchin. Paired controls for autogenic changes in mass were placed in identical tubs without urchins. After the urchins fed for $2.5 \mathrm{~d}$, the remaining pieces of algae were reweighed to the nearest milligram, and the amount consumed was calculated as before.

Tissue samples for analyses of nutritive and secondary metabolite content were collected after algae had recovered from the desiccation stress for $\approx 40 \mathrm{~h}$ in flowing seawater (i.e., as the urchin assay was started). Tissue samples for nutritive value analyses were frozen, lyophilized, ground into a fine powder, and stored at $-25^{\circ} \mathrm{C}$ until analyzed. Total carbon and nitrogen were determined with a $\mathrm{CN}$ analyzer. Soluble protein was measured using the Bradford (1976) analysis as modified by Duffy and Hay (1991). The concentration of each secondary metabolite was determined using methods of Cronin et al. (1995). Differences in the plant qualities measured above were analyzed with paired-sample $t$ tests because undesiccated and desiccated tissue came from the same plant. $P_{\text {two-taled }}$ values are given when no a priori predictions on the effect of desiccation on measured traits were made (e.g., res- 
piration and total carbon). $P_{\mathrm{dir}}$ values are reported for properties when a priori predictions were made.

To determine if changes in secondary metabolites alone could have altered Dictyota ciliolata palatability following desiccation, Ulva-based agar foods were treated with the mean concentrations of pachydictyol $\mathrm{A}$ and dictyol $\mathrm{B}$ acetate present in either the undesiccated or the desiccated plants, resulting in an "undesiccated mimic" and a "desiccated mimic" with respect to these two secondary metabolites. We offered the following choices to two separate groups of 20 urchins: (1) untreated control vs. undesiccated mimic, and (2) untreated control vs. desiccated mimic.

\section{UV irradiance}

When low tides occur during daylight hours or when inshore waters become unusually clear, shallow Dictyota ciliolata can experience high levels of ultraviolet (UV) radiation. The effect of surface level UV radiation on D. ciliolata was assessed by growing plants under UV-blocking (UF3) or UV-transparent (UVT) Plexiglas. UF3 Plexiglas absorbs $100 \pm 0.2 \%$ of UVA radiation and $89 \pm 0 \%$ of UVB radiation while UVT Plexiglas absorbs only $9 \pm 1 \%$ and $13 \pm 2 \%$ of UVA and UVB, respectively (means $\pm 1 \mathrm{SE}$, based on six determinations using natural light at midday with Spectroline DM-365X and DM-300X UV meters). UF3 and UVT transmit photosynthetically active radiation (PAR, wavelengths from 430 to $700 \mathrm{~nm}$ ) identically, both attenuating these wavelengths $\approx 10 \%$ (N. Lindquist, personal communication).

For the UV experiment, Dictyota ciliolata plants were split in half, weighed, and randomly assigned to one of two treatments, either grown under UF3 or UVT. A floating rack fabricated with polyvinyl chloride (PVC) pipes supported 24 panes of Plexiglas (12 UF3 and 12 UVT; each $26 \times 42 \mathrm{~cm}$ ) that were systematically interspersed so each replicate had paired panes of UF3 and UVT adjacent to each other. A frame of PVC pipe with thin plastic mesh stretched across it was attached to the underside of the floating rack. Plants were attached to this plastic mesh with cable ties, resulting in the algae being held $\approx 4 \mathrm{~cm}$ below the water surface and $\approx 7 \mathrm{~cm}$ below the Plexiglas, although these distances varied with wave conditions. Four halves from two plants were placed under each pair of UVT and UF3. The floating rack and algae were deployed in Bogue Sound, North Carolina, behind the Institute of Marine Sciences from 10 to 16 October 1993.

After the 6-d treatment, algae were reweighed and their apparent health was scored as dead, bleached, or healthy. A Fisher's exact test was performed on the apparent healthiness of plants, with "not healthy" (i.e., bleached or dead) and "healthy" as the two categories. Dead plants were not used in further assays. Productivity, respiration, tissue toughness, soluble protein, and concentrations of secondary metabolites were measured as described above.
The resistance of the algae to grazing by the amphipod Ampithoe longimana was determined using procedures modified from the assay performed with desiccated and undesiccated algae. A portion of each half from the same plant that had been placed under the UF3 and UVT Plexiglas was offered to 13 groups of seven amphipods in plastic dishes containing $\approx 100 \mathrm{~mL}$ of seawater. Paired algae placed in dishes without amphipods were used to control for autogenic changes in mass. After the first day, 2-4 amphipods were added to replicates where little tissue was being consumed. This assay ran for $2.5 \mathrm{~d}$. Because plants were paired by genotype (i.e., came from the same plant), a pairedsample $t$ test was used to determine $P_{\mathrm{drr}}$ for each variable measured.

\section{Urchin hunger stress}

To assess the effect of hunger stress on urchin feeding patterns, feeding assays using $0.2 \%$ DM pachydictyol $\mathrm{A}$ in artificial algal food were performed with a group of urchins that had been starved for $3 \mathrm{~d}$ and another group that had been fed during this period. Pachydictyol A was used in these assays because it can deter urchins at $0.2 \% \mathrm{DM}$, it is a common metabolite among Dictyota spp. and three other genera of Dictyotales (see references in Hay et al. 1987b), and it is the only stable secondary metabolite produced by both species of Dictyota that commonly grow in North Carolina (D. ciliolata and D. menstrualis) (Cronin et al. 1995).

Forty urchins were taken from outdoor holding ponds where they had access to abundant food and were placed in individual tubs as explained above. The tubs were interspersed in flow-through seawater tables. The "fed" group of urchins was offered the palatable alga (Hay et al. 1986) Gracilaria tikvahiae ad libitum for $3 \mathrm{~d}$ prior to the first feeding assay and between the four feeding assays conducted on four consecutive days. The "starved" group was deprived of food for $3 \mathrm{~d}$ prior to the first feeding assay as well as between the four feeding assays. On each of four consecutive days, all urchins in both groups were offered a choice between Ulva-based agar food treated with $0.2 \%$ DM pachydictyol A and equivalent control food that lacked pachydictyol A.

To take advantage of the paired design, $P_{\mathrm{dir}}$ was calculated with paired-sample $t$ tests to determine if $0.2 \%$ pachydictyol A deterred feeding on each day of the assay. For each of the $4 \mathrm{~d}$, a two-sample $t$ test also was performed to determine if the total amount of food consumed (i.e., control food + treatment food) differed between the "starved" and "fed" urchins. $P_{\text {two-talled }}$ values were used when comparing the total amount of food consumed by the different groups of urchins because no a priori predictions were made.

\section{RESULTS}

\section{Palatability of Dictyota}

As predicted, both the pinfish $\left(P_{\mathrm{dir}}<0.00001\right)$ and the sea urchin $\left(P_{\mathrm{d} \text { r }}=0.004\right)$ preferred Hypnea mus- 

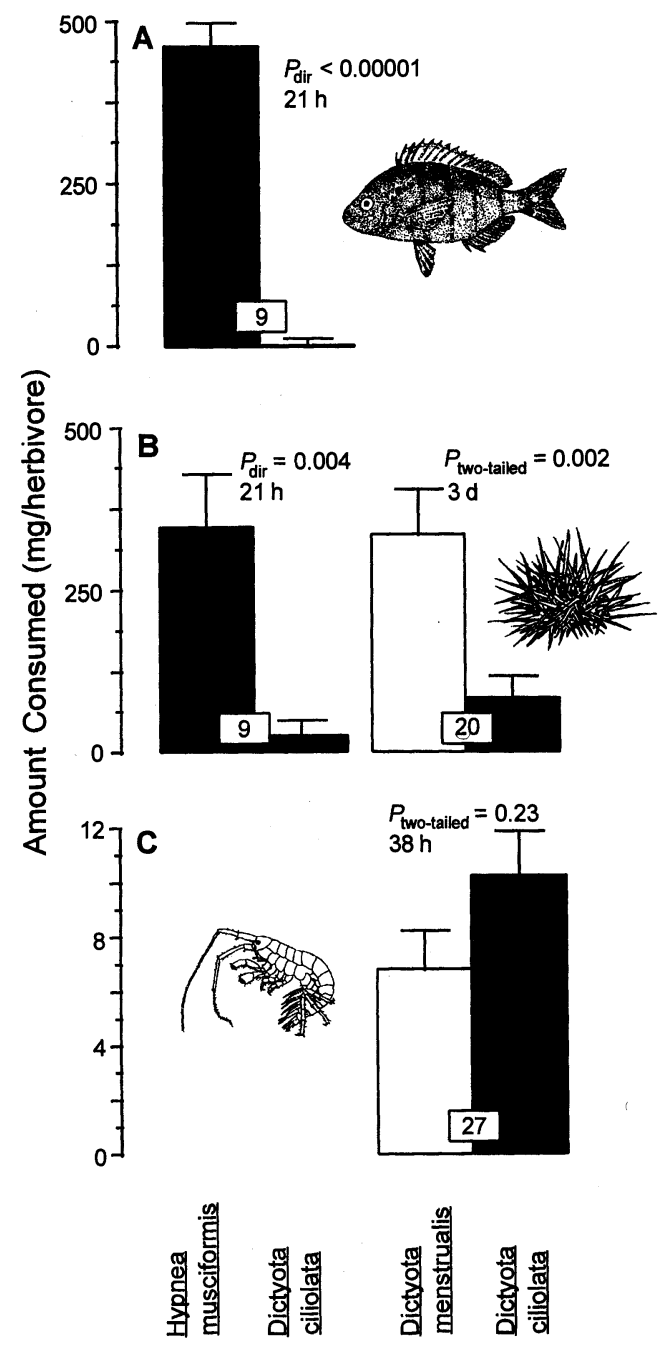

FIG. 1. Relative palatability of Dictyota ciliolata compared to the red alga Hypnea musciformis and the congener Dictyota menstrualis when offered to (A) the pinfish Lagodon rhomboides, (B) the sea urchin Arbacia punctulata, and (C) the amphipod Ampithoe longimana. Bars represent mean (+1 SE) mass of seaweed consumed per individual herbivore during the feeding assay. Sample size is given in the box at the base of paired bars. The duration of each feeding assay is indicated and $P$ values are calculated from paired-sample $t$ tests.

ciformis over D. ciliolata (Fig. 1). In fact, the amount of $D$. ciliolata consumed by pinfish or sea urchins in these $21-\mathrm{h}$ assays did not differ significantly from zero $\left(P_{\mathrm{dir}}=0.49\right.$ and 0.19 , respectively).

Sea urchins consumed 4 times more $D$. menstrualis than $D$. ciliolata in a no-choice assay $\left(P_{\text {two-tailed }}=0.002\right.$, Fig. 1B). Ampithoe longimana did not show a significant preference between the two species as food $\left(P_{\text {two- }}\right.$ tailed $=0.23$ ), although consumption of $D$. ciliolata was $\approx 50 \%$ greater than that of $D$. menstrualis (Fig. 1C). However, $A$. longimana initially preferred to reside on D. ciliolata (17 amphipods on D. ciliolata vs. 9 on D. menstrualis; $0.025<P_{\text {two-tailed }}<0.05$; chi-squared).

This preference for D. ciliolata was also documented $37 \mathrm{~h}$ into the assay $\left(20\right.$ vs. $\left.7 ; P_{\text {two-tailed }}<0.001\right)$. At 17 $\mathrm{h}$ into the assay, the same trend occurred, but it was not significant (17 vs. $11 ; 0.1<P_{\text {two-tailed }}<0.25$ ).

\section{Effects of secondary metabolites on herbivore feeding behavior}

Test compounds were always detected in treated food at the end of feeding assays and no breakdown products were apparent. Thus, differences in the amount of food consumed are likely due to the presence/absence of test compounds.

Pachydictyol A did not deter pinfish feeding at natural, or even at 2.5 times natural, concentrations (Fig. $2 \mathrm{~A}$ ). Feeding was significantly reduced at $\approx 5$ times natural concentration, which is a concentration that may occur in other species of Dictyota and related genera (Hirschfeld et al. 1973, McEnroe et al. 1977, Hay et al. 1987b). Ampithoe longimana was not deterred by the highest natural concentration (i.e., $0.2 \% \mathrm{DM}$ ) of pachydictyol A found in species of Dictyota occurring in North Carolina (Cronin et al. 1995), but was deterred at 2.5 times natural concentration (Fig. 2C). In contrast to the pinfish and amphipod, the urchin was deterred by concentrations of pachydictyol A that occur naturally in $D$. ciliolata. Thus, natural concentrations of pachydictyol $\mathrm{A}$ alone can deter the urchin, but not the fish or amphipod, from consuming D. ciliolata.

Dictyol B acetate differs structurally from pachydictyol A only by having a hydrogen atom replaced by an acetate group (compare structures in Figs. 2 and 3); however, it is much more deterrent to the urchin and pinfish. Dictyol B acetate alone deterred all three herbivores at concentrations found in D. ciliolata and even deterred $L$. rhomboides and A. punctulata at $\approx 15-25 \%$ and $4-6 \%$ of natural concentrations, respectively (Fig. 3A, B). At 73-116\% of natural concentration, dictyol $\mathrm{B}$ acetate reduced feeding by Ampithoe longimana but had no effect on Ampithoe feeding at 36-58\% of natural concentration (Fig. 3C).

The dictyol fraction from freeze-dried $D$. menstrualis contained $69 \%$ less dictyodial than the dictyol fraction from the same collection of $D$. menstrualis that was not freeze-dried. Lagodon rhomboides and Ampithoe longimana did not distinguish between foods treated with these different dictyol fractions but Arbacia punctulata significantly preferred food treated with the extract having the lower concentration of dictyodial (Fig. 4). Unfortunately, the two dictyol fractions also differed in compounds other than dictyodial; the dictyol fraction from freeze-dried tissue also had $4 \%$ less pachydictyol A ( $0.046 \%$ vs. $0.048 \%$ DM), $11 \%$ less dictyol E $(0.17 \%$ vs. $0.19 \%$ DM), $6 \%$ less sterols, $15 \%$ less of an unknown compound, and $250 \%$ more of another unknown compound than the dictyol fraction obtained from tissue that was not freeze-dried (all based on highpressure liquid chromatography analyses using methods of Cronin et al. 1995). Urchins are not deterred by 

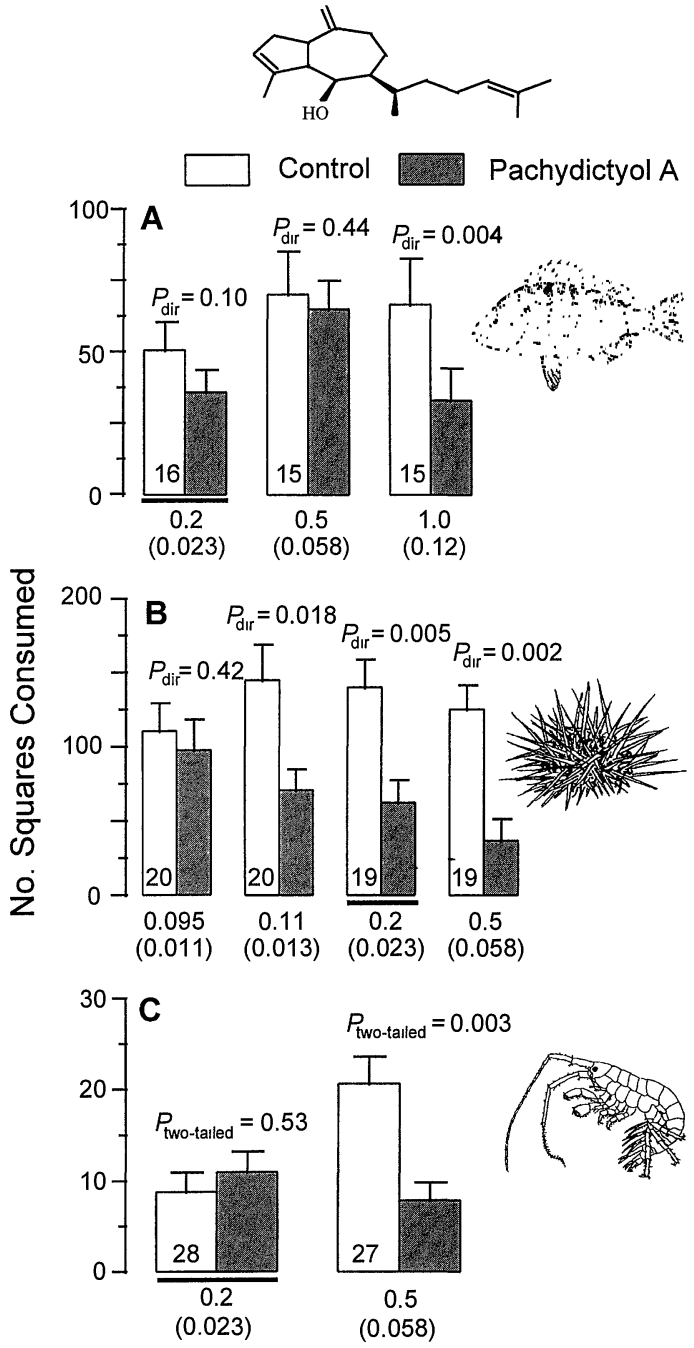

Concentration as \% Dry Mass (\% Wet Mass)

FIG. 2. The effect of pachydictyol A on the feeding behavior of the (A) pinfish, (B) sea urchin, and (C) amphipod. Sample size is given at the bottom of each control bar. The tested concentrations of pachydictyol A increase from left to right and are given below each pair of bars as both percent of plant dry mass and percent of plant wet mass. The upper end of the natural concentration range of this compound found in our populations of $D$. ciliolata is $0.2 \%$ dry mass; this is indicated as a dark bar beneath this concentration. Bars are the mean +1 SE amount of food consumed per replicate (i.e., individual pinfish, urchin, or group of 4-6 amphipods). $P$ values are from paired-sample $t$ tests.

these levels of pachydictyol A (Hay et al. 1987a, Fig. 2B) or dictyol E (Hay et al. 1987a), but it is unknown whether the differences in sterols or the two unknown compounds could be responsible for the different effects of the two dictyol fractions on sea urchin feeding. Thus, our findings are consistent with the hypothesis that dictyodial deters urchins but not pinfish and $\mathrm{Am}$ pithoe longimana; however, we cannot exclude the possibility that differing levels of the other compounds were responsible for the observations.

\section{Desiccation}

The only visible change in $D$. ciliolata resulting from desiccation was that the top $1 \mathrm{~cm}$ or so of blades changed from the normal brown color to green, became less rigid, and senesced. The rest of the plant showed no visually apparent change and was apparently stressed, but not killed, given that it continued to photosynthesize and respire, though at altered rates. Desiccation decreased photosynthesis by $47 \%\left(P_{\mathrm{dir}}=\right.$ $0.0002)$ and increased respiration by $40 \%\left(P_{\text {two-talled }}=\right.$ 0.064, Table 1).

Desiccation also influenced algal susceptibility to cooccurring herbivores. The urchin Arbacia punctulata consumed $237 \%$ more desiccated than undesiccated Dictyota ciliolata in a no-choice feeding assay $\left(P_{\mathrm{dir}}=\right.$ $0.0029)$ and the amphipod Ampithoe longimana consumed $161 \%$ more of the desiccated tissue $\left(P_{\mathrm{dir}}=\right.$

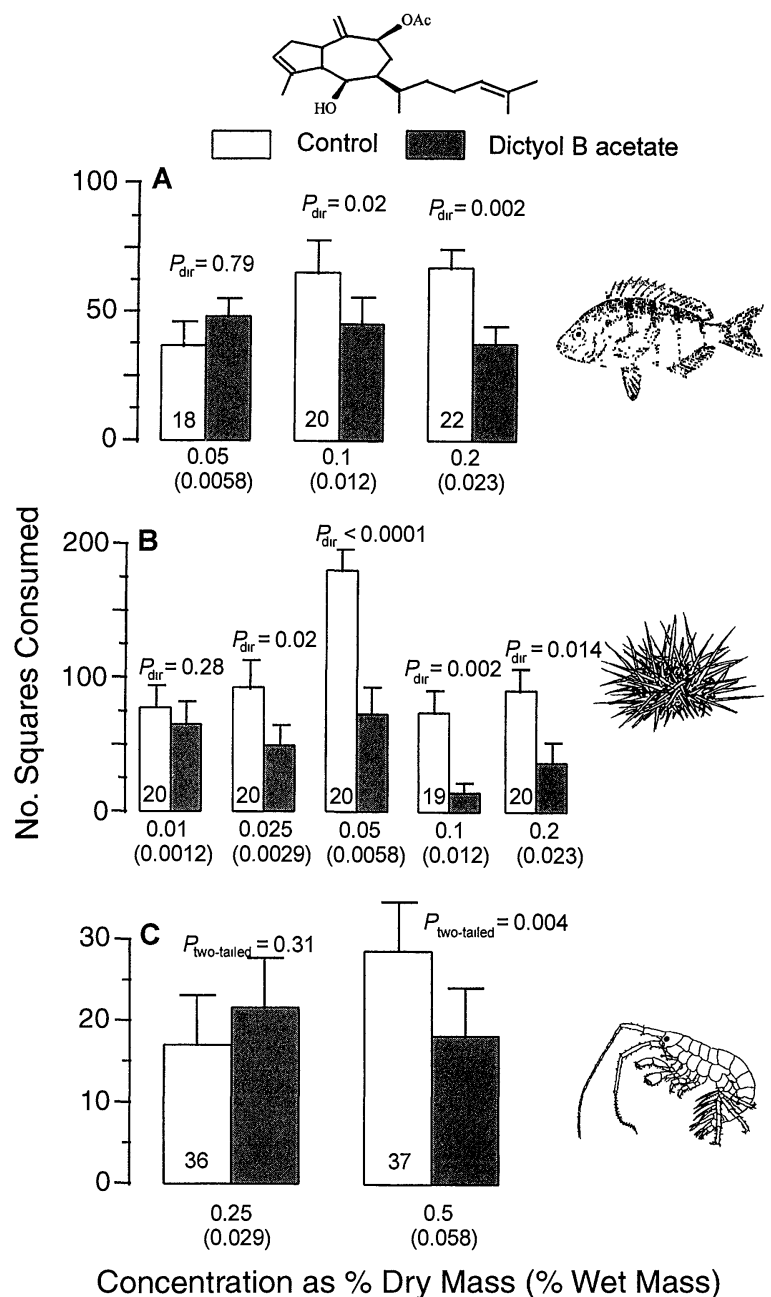

FIG. 3. The effect of dictyol $B$ acetate of the feeding behavior of the (A) pinfish, (B) sea urchin, and (C) amphipod. Other symbols are as in Fig. 2. The natural concentration of dictyol B acetate in our populations of $D$. ciliolata range from 0.4 to $0.7 \%$ of plant dry mass. Thus, all concentrations tested were below maximum natural concentrations. 


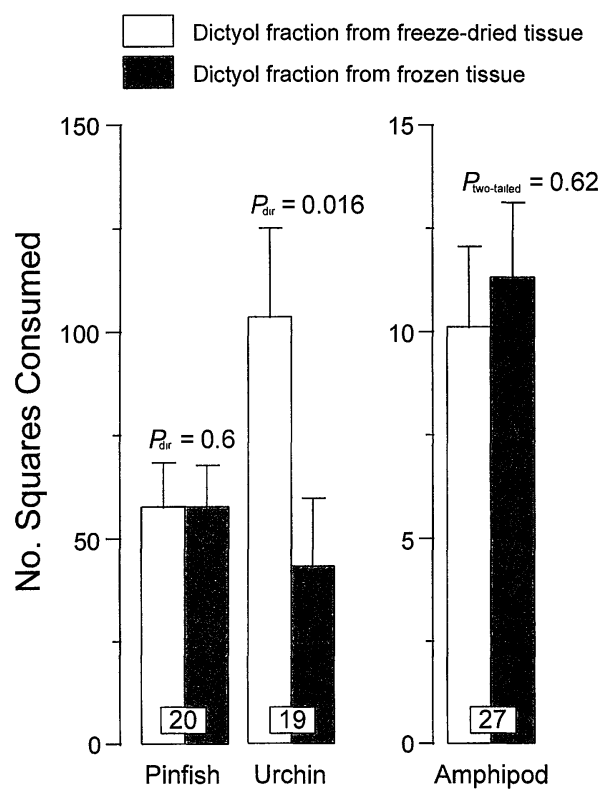

FIG. 4. The effect of the "dictyol fractions" from a single collection of Dictyota menstrualis, half of which was freeze dried before being extracted and the other half of which was extracted without freeze drying. This was an attempt to test the effect of dictyodial on herbivore feeding behavior; dictyodial concentration was reduced $69 \%$ when D. menstrualis was freeze dried. However, the two "dictyol fractions" differed in other compounds as well. Sample size is given at the bottom of each pair of bars. Bars are the mean +1 SE amount of food consumed per replicate. $P$ values are from pairedsample $t$ tests.

0.0022 ) when offered a choice between desiccated and undesiccated $D$. ciliolata (Table 1). Neither tissue toughness $\left(P_{\mathrm{dir}}=0.77\right)$ nor tissue nutritive value (total carbon, $P_{\text {two-tailed }}=0.17$; total nitrogen, $P_{\text {dir }}=0.18$; soluble protein, $\left.P_{\text {dir }}=0.27\right)$ changed significantly following desiccation, and two of the three small (4-15\%) and nonsignificant changes that did occur were in the direction that should have decreased, rather than increased, feeding. Thus, changes in toughness or nutritive value following desiccation could not explain the changes in Dictyota susceptibility to consumers. In contrast, concentrations of pachydictyol A, dictyol B acetate, and dictyodial decreased by $7 \%\left(P_{\mathrm{dir}}=0.061\right)$, $17 \%\left(P_{\mathrm{dir}}=0.0004\right)$, and $38 \%\left(P_{\mathrm{dir}}=0.008\right)$, respectively (Table 1 ). Together, the above data suggest that desiccation increased susceptibility to herbivores by compromising the seaweed's chemical defenses.

When compared to control foods without metabolites, the average concentrations of pachydictyol $\mathrm{A}$ and dictyol B acetate found in undesiccated plants (i.e., undesiccated mimic) reduced feeding by a significant $77 \%\left(P_{\mathrm{dir}}=0.001\right)$, while the average concentrations of these compounds found in desiccated plants (i.e., desiccated mimic) had no significant effect on feeding $\left(P_{\mathrm{dir}}=0.33\right.$, Fig. 5). The large decrease in consumption of the undesiccated mimic was significantly greater than the small decrease in consumption of the desiccated mimic (i.e., the mean differences between the mimic and the control foods in the two assays were significantly different; $P_{\mathrm{d} \mathrm{r}}=0.019$, two-sample $t$ test), indicating that the undesiccated mimic was significantly more deterrent.

\section{UV irradiance}

Prolonged exposure to surface levels of UV radiation was physiologically detrimental to Dictyota ciliolata (Table 2). Seventy percent of the D. ciliolata plants transplanted under UV-transparent Plexiglas (UVT) for $6 \mathrm{~d}$ became bleached or died (Table 2) while all of the plants grown under UV-absorbing Plexiglas (UF3) appeared pigmented and healthy at the end of the 6-d experiment $(P \ll 0.001$, Fisher's exact test, Table 2$)$. Plants screened from UV radiation grew 6.1 times more than plants exposed to UV radiation (Table 2); the changes in mass were due to Dictyota growth and not epiphytes, which did not colonize plants during the experiment. Despite the high incidence of bleaching in Dictyota ciliolata exposed to surface levels of UV radiation, net photosynthesis (at $\approx 200 \mu \mathrm{mol}$ photon $\cdot \mathrm{m}^{-2} \cdot \mathrm{s}^{-1}$ ) and respiration did not differ significantly between UV-screened and UV-exposed algae when re-

TABLE 1. The effect of desiccation on the physiology, resistance to herbivores, toughness, nutritive value, and secondary metabolites of Dictyota ciliolata.

\begin{tabular}{|c|c|c|c|c|c|}
\hline Measurement & $\begin{array}{l}\text { Undesiccated } \\
(\text { mean } \pm 1 \mathrm{SE})\end{array}$ & $\begin{array}{c}\text { Desiccated } \\
(\text { mean } \pm 1 \mathrm{SE})\end{array}$ & $\begin{array}{c}\% \\
\text { change }\end{array}$ & $N$ & $P^{*}$ \\
\hline Productivity $\left(\mathrm{mg} \mathrm{O}_{2} \cdot \mathrm{g} \mathrm{WM}^{-1} \cdot \mathrm{h}^{-1}\right)$ & $3.0 \pm 0.2$ & $1.4 \pm 0.2$ & -53 & 9 & 0.0002 \\
\hline Respiration $\left(\mathrm{mg} \mathrm{O}_{2} \cdot \mathrm{g} \mathrm{WM}^{-1} \cdot \mathrm{h}^{-1}\right)$ & $0.15 \pm 0.02$ & $0.21 \pm 0.01$ & +40 & 9 & $0064 \dagger$ \\
\hline Urchin consumption $\left(\mathrm{mg} \cdot \mathrm{urchin}^{-1} \cdot \mathrm{d}^{-1}\right)$ & $9.2 \pm 3.6$ & $31.0 \pm 5.4$ & +237 & 18 & 0.0029 \\
\hline Amphipod consumption $\left(\mathrm{mg} \cdot\right.$ amphipod $\left.^{-1} \cdot \mathrm{d}^{-1}\right)$ & $3.12 \pm 0.95$ & $8.15 \pm 1.06$ & +161 & 24 & 0.0022 \\
\hline Toughness $(\mathrm{N})$ & $0.057 \pm 0.004$ & $0.059 \pm 0.004$ & +4 & 25 & 0.77 \\
\hline Total carbon (\%DM) & $25.0 \pm 1.3$ & $23.1 \pm 10.8$ & -8 & 10 & $0.17 \dagger$ \\
\hline Total nitrogen (\%DM) & $1.78 \pm 0.09$ & $1.89 \pm 0.09$ & +6 & 10 & 0.18 \\
\hline Soluble protein (\%DM) & $1.01 \pm 0.06$ & $0.86 \pm 0.08$ & -15 & 15 & 0.27 \\
\hline Pachydictyol A (\%WM) & $0.0099 \pm 0.0007$ & $0.0092 \pm 0.0006$ & -7 & 12 & 0.061 \\
\hline Dictyol B acetate (\%WM) & $0.088 \pm 0.005$ & $0.073 \pm 0.004$ & -17 & 12 & 0.0004 \\
\hline Dictyodial (relative concentration) & $0.090 \pm 0.011$ & $0.056 \pm 0.007$ & -38 & 12 & 0.008 \\
\hline
\end{tabular}

* $P_{\mathrm{dir}}$ values (sensu Rice and Gaines 1994) are from paired-sample $t$ tests except for those marked with a " $\dagger$ ", which are two tailed because directed a priori predictions were not made. 


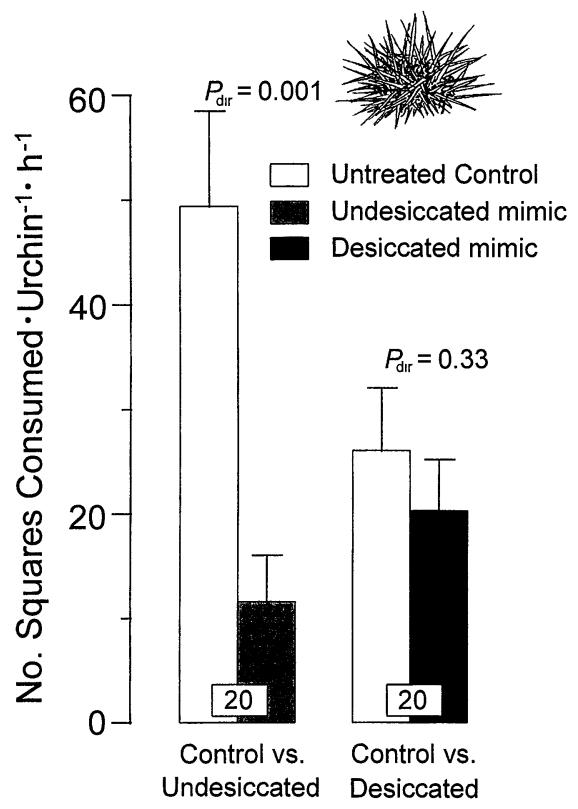

FIG. 5. The effects of pachydictyol A and dictyol B acetate combined to mimic the concentrations found in undesiccated and desiccated Dictyota ciliolata on the feeding behavior of sea urchins. Symbols are as in Fig. 2. The mean difference in feeding on the control vs. undesiccated mimic was significantly greater than the mean difference for the 'control vs. desiccated mimic ( $P_{\mathrm{dr}}=0.019$, two-sample $t$ test $)$.

maining portions of plants from both treatments were incubated in the laboratory (Table 2). However, these photosynthetic and respiration rates are similar to those measured in desiccation-stressed $D$. ciliolata (Table 1), suggesting that plants grown under either UV-blocking or UV-transparent plates may have been stressed by the conditions they experienced during the 6-d experiment.

Because of the low growth and poor survivorship of plants exposed to UV radiation, we lacked adequate tissue to assess the alga's resistance to large herbivores such as urchins. However, Ampithoe longimana did not distinguish between the UV-exposed plants and the UVscreened plants $\left(P_{\mathrm{dr}}=0.11\right.$, Table 2$)$, even though the UV-exposed plants tended to have lower levels of sec- ondary metabolites. Plants grown under UV exposure had pachydictyol A, dictyol B acetate, and dictyodial concentrations that were reduced by $43 \%\left(P_{\mathrm{dir}}=0.13\right)$, $45 \%\left(P_{\mathrm{dir}}=0.072\right)$, and $64 \%\left(P_{\mathrm{dir}}=0.027\right)$ compared to plants screened from UV (Table 2). Soluble protein and tissue toughness did not differ between plants subjected to different levels of UV radiation $(P=0.41)$.

\section{Urchin hunger stress}

Starved urchins generally fed less discriminately than urchins that had been fed (Fig. 6). On Day 1 , previously fed urchins significantly avoided the pachydictyol A treated food $\left(P_{\mathrm{dir}}=0.005\right)$. In contrast, the starved urchins did not distinguish between the two food types $\left(P_{\mathrm{dr}}=0.18\right)$ and they consumed more total food (i.e., control plus treated food) than the fed urchins $\left(P_{\text {two-tailed }}=0.038\right)$. On Day 2 , the fed urchins again avoided the treated food $\left(P_{\mathrm{d} \text { r }}=0.037\right)$ while the starved urchins continued to be undeterred $\left(P_{\text {dir }}=\right.$ 0.92 ), and in fact, consumed more of the treated food. As on Day 1, the starved urchins consumed more total food than fed urchins $\left(P_{\text {two-taled }}=0.001\right)$. On Day 3, both the fed and starved urchins significantly avoided the treated food $\left(P_{\mathrm{dir}}=0.0004\right.$ and 0.007 , respectively), even though the starved urchins continued to consume more total food than the fed urchins $\left(P_{\text {two-taled }}=0.031\right)$. On Day 4 , both groups of urchins behaved similarly. The fed and starved urchins both consumed more control than treatment food $\left(P_{\mathrm{d} \text { ir }}=0.004\right.$ and 0.0004 , respectively) and there was no difference in the total amount of food consumed by each group of urchins $\left(P_{\text {two-talled }}=0.36\right)$. It appears that the starved group of urchins had eaten enough assay food during the first three feeding experiments that they were no longer starved, but instead began behaving like fed urchins.

It is important to note that the reason starved urchins were not deterred by pachydictyol A on Days 1 and 2 was not because they first consumed all the control food and were then left no choice but to consume the remaining treated food. For Day 1, every urchin that chose the food treated with pachydictyol A (i.e., consumed more treated food than control food) still had

TABLE 2. The effect of UV radiation on the physiology, resistance to amphipod grazing, toughness, nutritive value, and secondary metabolites of Dictyota ciliolata.

\begin{tabular}{|c|c|c|c|c|c|}
\hline Measurement & UF3 (UV screened) & UVT (UV exposed) & $\%$ change & $N$ & $P^{*}$ \\
\hline Number healthy/total & $15 / 15$ & $6 / 20$ & -70 & $\ldots$ & $0.00001 \dagger$ \\
\hline Relative growth/day & $6.25 \pm 1.3 \%$ & $1.02 \pm 1.2 \%$ & -84 & 14 & 0.014 \\
\hline Productivity $\left(\mathrm{mg} \mathrm{O}_{2} \cdot \mathrm{g} \mathrm{WM}^{-1} \cdot \mathrm{h}^{-1}\right)$ & $1.7 \pm 0.2$ & $1.5 \pm 0.2$ & -12 & 8 & 0.17 \\
\hline Respiration $\left(\mathrm{mg} \mathrm{O}_{2} \cdot \mathrm{g} \mathrm{WM}^{-1} \cdot \mathrm{h}^{-1}\right)$ & $0.19 \pm 0.01$ & $0.22 \pm 0.03$ & +16 & 8 & 0.22 \\
\hline Amphipod consumption $\left(\mathrm{mg} \cdot\right.$ amphipod $\left.^{-1} \cdot \mathrm{d}^{-1}\right)$ & $1.36 \pm 0.17$ & $1.80 \pm 0.23$ & +32 & 13 & 0.11 \\
\hline Toughness $(\mathrm{N})$ & $0.065 \pm 0.006$ & $0.061 \pm 0.004$ & -6 & 13 & 0.41 \\
\hline Soluble protein (\%DM) & $0.60 \pm 0.03$ & $0.62 \pm 0.05$ & +3 & 7 & 0.41 \\
\hline Pachydictyol A (\%WM) & $0.0021 \pm 0.0004$ & $0.0012 \pm 0.0004$ & -43 & 8 & 0.13 \\
\hline Dictyol $B$ acetate $(\% \mathrm{WM})$ & $0.042 \pm 0.008$ & $0.023 \pm 0.005$ & -45 & 8 & 0.072 \\
\hline Dictyodial (relative concentration) & $0.064 \pm 0.014$ & $0.023 \pm 0.007$ & -64 & 8 & 0.027 \\
\hline
\end{tabular}

$* P_{\mathrm{d} \text { r }}$ values were calculated with paired-sample $t$ tests except for the $P_{\mathrm{d} \text { r }}$ value for the number of healthy plants ( $\dagger$ ), which was calculated with Fisher's exact test. 


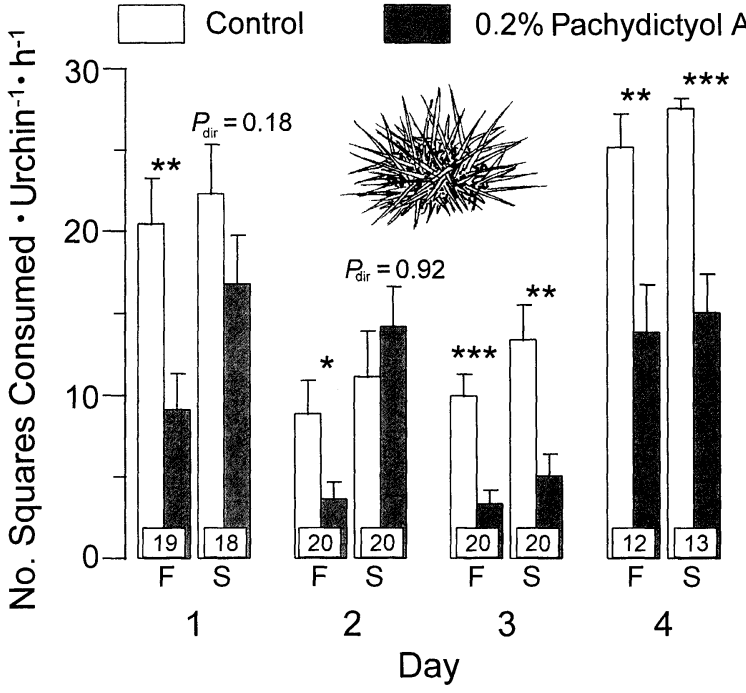

FIG. 6. The effects of starvation stress on the feeding behavior of the sea urchin Arbacia punctulata. A fed (F) and a starved (S) group of urchins were offered a choice between untreated control food and food treated with $0.2 \%$ DM (dry mass) pachydictyol A on each of four consecutive days. Asterisks above a pair of bars indicate that pachydictyol A significantly deterred the urchins as determined with pairedsample $t$ tests $\left(*=0.01<P_{\mathrm{dir}}<0.05 ; * *=0.001<P_{\mathrm{dir}}<\right.$ $\left.0.01 ; * * *=P_{\mathrm{dir}}<0.001\right)$. Sample size is given at the bottom of each pair of bars. Bars are the mean +1 SE amount of food consumed per replicate. $P$ values are from paired-sample $t$ tests.

$36-100 \%$ of the initial control food available to them at the end of the experiment. On Day 2, urchins that chose the treated food had 73-100\% of the control food remaining. Finally, during the assay performed on Day 4, starved urchins had less control food available to them at the end of the experiment than they did on Days 1 or 2, yet they still significantly avoided the food treated with pachydictyol A.

\section{DISCUSSION}

Seaweed chemical defenses against herbivores were clearly affected by desiccation and potentially by nearsurface levels of UV radiation (Tables 1 and 2). One hour of desiccation resulted in lowered concentrations of chemical defenses and significantly increased susceptibility to both urchin and amphipod grazing (Table 1). Urchin grazing assays using artificial plants that mimicked levels of pachydictyol A and dictyol B acetate in desiccated vs. undesiccated plants demonstrated that these changes in palatability could result from the differing levels of chemical defenses alone (Fig. 5). Exposure to near-surface levels of UV radiation also tended to decrease chemical defenses and to increase susceptibility to amphipod grazing (Table 2). The changes that occurred in the UV experiment are suggestive but rarely statistically significant. Our power to detect significant changes was compromised when many of the UV-stressed plants died and limited our available sample size. Separate and more powerfully designed experiments on the effects of UV radiation have shown that $D$. ciliolata becomes significantly more susceptible to Arbacia grazing after as little as 3-6 h of exposure to near-surface levels of UV and that levels of Dictyota chemical defenses are significantly decreased by UV exposure (M. E. Hay, S. Johnson, and N. Lindquist, unpublished data). These shortterm (hours) exposures to near-surface UV occur normally in North Carolina during low tides. The longer term (6-d) exposure to UV created in our experiment would rarely, if ever, occur in North Carolina but could occur in many parts of the Caribbean where D. ciliolata is common and where local weather patterns overwhelm lunar tides and create low tides that can last for several days (see Fig. 2 in Hay 1981 as an example).

In terrestrial communities, stress-induced increases in plant palatability have been hypothesized to result from increases in nutritive value (White 1984) or decreases in defensive characters (Rhoades 1985). Neither changes in nutritive value (total nitrogen or soluble protein) nor in toughness explain the increase in palatability of $D$. ciliolata following stress. However, concentrations of pachydictyol A, dictyol B acetate, and dictyodial decreased following desiccation (Table 1), or exposure to near-surface UV radiation (Table 2). At natural concentrations, each of these compounds alone appears to deter urchins and one of them deters $A$. longimana (Figs. 2-4), thus the combined effect of decreases in all of these secondary metabolites may account for the increase in palatability (Fig. 5).

Compromised chemical defenses may be a general outcome of physical stress in chemically defended plants. The stress-induced changes in plant susceptibility that we found in this study are consistent with Renaud et al.'s (1990) predictions that stress of unpalatable seaweeds will increase their susceptibility to generalist herbivores via loss of chemical defenses, while stress of palatable seaweeds may decrease their susceptibility via decreases in nutritive value. They found that desiccation of the unpalatable brown alga Padina gymnospora resulted in its becoming more palatable to urchins and that this increased palatability was related to losses of deterrents in the lipid-soluble extract and was not due to changes in soluble protein content. In contrast, the normally palatable red alga Gracilaria tikvahiae became less palatable when desiccated and this was associated with a decline in protein content. Dictyota ciliolata fits with the general patterns proposed by Renaud et al. (1990) in that it is relatively unpalatable in its unstressed state but becomes more palatable and loses chemical defenses when physically stressed.

A few studies have experimentally addressed the effects of algal stress on seaweed-herbivore interactions (Van Alstyne 1988, Renaud et al. 1990, Cronin and Hay, in press) and the effects of starvation stress on the growth (Levitan 1989, Rowley 1990), survivorship 
(Rowley 1990, Duffy and Hay 1991), and feeding rates (Bishop and Watts 1994) of marine herbivores, but experimental assessments of how short periods of hunger affect herbivore feeding preferences are rare. That herbivores are often hungry in the field is suggested by observations and experiments showing that several marine herbivores experience low resource availability, or food limitation, on heavily grazed reefs (Robertson 1982, Hay and Taylor 1985, Morrison 1988, Levitan 1989, Carpenter 1990) and that low abundance of seaweeds can even result in death of herbivores under field conditions (Tsuda and Bryan 1973).

Just as physical stresses on Dictyota ciliolata altered its chemical defenses and susceptibility to herbivores, the stress associated with a short (3-d) deprivation of food altered sea urchin feeding rates and responsiveness to a defensive algal metabolite. Fed urchins immediately and consistently decreased their intake of pachydictyol A treated food, while starved urchins did not significantly decrease feeding on treated food until the 3rd and 4th $\mathrm{d}$ of the experiment (Fig. 6). These changes in feeding behavior following short periods of starvation can have important implications for the interpretation of results from laboratory feeding assays. When consumers are starved prior to feeding trials in order to make them feed more quickly, their feeding behavior may be altered and results may be misinterpreted. For example, by observing the feeding behavior of starved urchins on Days 1 and 2, one would conclude that pachydictyol A does not influence urchin feeding behavior. This was the conclusion drawn by Hay et al. (1987a) after offering algae coated with $1.3 \%$ DM pachydictyol A to Arbacia punctulata. The concentration of pachydictyol A they added to seaweed as a thin surface layer was nearly 12 times the concentration we found to be deterrent when the compound was evenly mixed throughout the food and offered to unstarved urchins (Fig. 2). The difference in results was not due to the different methodologies (i.e., coating fresh Gracilaria vs. freeze-dried Ulva that was embedded in agar); coating pachydictyol A onto Gracilaria at $0.2 \%$ DM using methods similar to Hay et al. (1987a) significantly reduced feeding of well-fed urchins by $47 \%\left(P_{\mathrm{d} \text { r }}\right.$ $=0.031$, paired-sample $t$ test, $N=15$, G. Cronin, personal observation). The recent feeding history of urchins used by Hay et al. (1987a) was not reported, but urchins were not fed shortly before assays as they were for the current paper (M. E. Hay, personal observation). Additionally, data from the assays using starved urchins could be misinterpreted to suggest that Arbacia punctulata were learning to avoid pachydictyol A (i.e., it took $2 \mathrm{~d}$ of "learning" before they avoided the pachydictyol A treated foods on Days 3 and 4). Because well-fed urchins immediately avoided the pachydictyol A treated foods, the pattern seen for starved urchins is clearly not a result of learning, but more likely results from decreased selectivity with increased hunger. If we had not simultaneously assayed the fed group of ur- chins, our results would have been ambiguous, and possibly misinterpreted. Unfortunately, starving consumers prior to laboratory assays is common. In a survey of 54 haphazardly selected papers in which laboratory feeding assays were performed with marine consumers (contact the authors for a list of papers), 33\% of the studies starved consumers before assays, $10 \%$ fed them before assays, and 57\% did not report how consumers were treated prior to the assays.

Other factors, unknown to us, must also influence the feeding selectivity of Arbacia punctulata. It is a paradox that $0.0029 \% \mathrm{WM}$ of dictyol B acetate significantly deterred the urchins in one assay (Fig. 3B), yet 25 times this amount (i.e., $0.073 \% \mathrm{WM}$ ) of dictyol $\mathrm{B}$ acetate plus $0.0092 \% \mathrm{WM}$ of pachydictyol A (i.e., the "desiccated mimic") did not significantly deter urchins (Fig. 5) in a separate assay. That urchins were deterred by $0.0029 \%$ WM because they were previously exposed to dictyol $\mathrm{B}$ acetate is not an adequate explanation because when those urchins were first used in assays, dictyol B acetate at $0.023 \% \mathrm{WM}$ was a strong deterrent (Fig. 3B). The only things that differed in these assays were the groups of urchins (e.g., they were collected in different years, although both groups were collected from Radio Island Jetty) and the date the assays were performed.

Just as fed vs. starved urchins differed in their responses to chemical defenses, large differences also occurred among herbivore species. Dictyota ciliolata and its congener Dictyota menstrualis are unpalatable to large generalist grazers such as the pinfish Lagodon rhomboides and the sea urchin Arbacia punctulata (Hay et al. 1987a, 1988; Fig. 1), and these herbivores are both deterred by natural concentrations of some of Dictyota's secondary metabolites (Hay et al. 1987a, 1988; Figs. 2 and 3). In contrast to the patterns for the fish and urchin, small, less mobile mesograzers like amphipods and polychaetes that live on the seaweeds they consume readily eat both Dictyota species (Hay et al. 1987a, 1988; Fig. 1). Because Dictyota species are low preference foods for omnivorous fishes, fishes visit these seaweeds less often than others and the seaweeds thus provide a refuge from predation for mesograzers like Ampithoe longimana (Hay et al. 1987a, 1988, 1990; Duffy and Hay 1991, 1994). Although Ampithoe longimana prefers $D$. ciliolata and D. menstrualis to most other seaweeds (compare patterns in Hay et al. $1987 a$ and Duffy and Hay 1991 with Fig. 1) and is generally less sensitive to Dictyota secondary metabolites than pinfish and urchins (Hay et al. 1987a; Duffy and Hay 1991, 1994; Figs. 2-4), natural concentrations of dictyol B acetate from $D$. ciliolata still significantly deter its feeding (Fig. 3C). Because $A$. longimana must balance the habitat and food value of an alga, it may prefer $D$. ciliolata, even though it contains deterrent levels of dictyol B acetate, because the alga offers a spatial escape from local predators (see 
Hay 1992, Duffy and Hay 1991, 1994 for similar examples).

Although it has been $16 \mathrm{yr}$ since Janzen (1979) warned that, "herbivores do not eat Latin binomials" and that "Latin binomials do not eat plants," many studies of ecological factors affecting plant populations and communities still treat plants as if they have fixed defensive traits and herbivores as if they have fixed behaviors and focus on physical factors alone or biological factors alone. For the plant-herbivore interactions we studied, the recent history of stresses experienced by either the plant or herbivore could substantially alter the fate of a particular plant when it is encountered by a particular herbivore. Additionally, laboratory feeding assays showing that a plant secondary metabolite deters a particular herbivore may not mean that that plant will be avoided in the field if the refuge value of the plant as a habitat offsets the negative effects of the secondary metabolites (also see Damman 1987, Hay 1992, Duffy and Hay 1994, Stachowicz and Hay 1996). Such conditional responses based on indirect, complex, or synergistic interactions are probably omnipresent in ecological systems (Hay 1986, Schmitt 1987, Peterson and Black 1988, Adler and Morris 1994, Billick and Case 1994, Bothwell et al. 1994, Kareiva 1994, Wootton 1994, Cronin and Hay, in press); adequately understanding their role in populations and communities will mandate greater integration among the many ecological subdisciplines.

\section{ACKNOWLEDGMENTS}

Funding was provided by NSF OCE $89-11872$ and OCE 92-02847 grants to M. E. Hay. We thank Julie Cronin and Buffy Turner for help with experiments. Carolyn Currin performed the $\mathrm{CN}$ analyses. Niels Lindquist provided the set-up to alter levels of UV radiation. Edwin Cruz, Steve Gaines, Niels Lindquist, Hans Paerl, Joe Pawlik, Charles Peterson, Jay Stackowicz, and two anonymous reviewers made invaluable recommendations that improved the manuscript.

\section{Literature Cited}

Adler, F. R., and W. F. Morris. 1994. A general test for interaction modification. Ecology 75:1552-1559.

Billick, I., and T. J. Case. 1994. Higher order interactions in ecological communities: What are they and how can they be detected? Ecology 75:1529-1543.

Bishop, C. D., and S. A. Watts. 1994. Two-stage recovery of gametogenic activity following starvation in Lytechinus variegatus Lamarck (Echinodermata: Echinoidea). Journal of Experimental Marine Biology and Ecology 177:27-36.

Bothwell, M. L, D. M. J. Sherbot, and C. M. Pollock. 1994. Ecosystem response to solar ultraviolet-B radiation: Influence of trophic-level interactions. Science 265:97-100.

Bradford, M. M. 1976. A rapid and sensitive method for the quantification of microgram quantities of protein utilizing the principle of protein-dye binding. Analytical Biochemistry 72:248-254.

Carpenter, R. C. 1990. Mass mortality of Diadema antillarum II. effects on population densities and grazing intensity of parrotfishes and surgeonfishes. Marine Biology 104:79-86.

Cronin, G., and M. E. Hay. In press. Amphipod grazing induces chemical defenses in the brown alga Dictyota menstrualis. Ecology.

Cronin, G., N. Lindquist, M. E. Hay, and W. Fenical. 1995.
Effects of storage and extraction procedures on yields of lipophilic metabolites from the brown seaweeds Dictyota ciliolata and Dictyota menstrualis. Marine Ecology Progress Series 119:265-273.

Damman, H. 1987. Leaf quality and enemy avoidance by the larvae of a pyralid moth. Ecology 68:88-97.

Duffy, J. E., and M. E. Hay. 1990. Seaweed adaptations to herbivory. BioScience 40:368-375

Duffy, J. E., and M. E. Hay. 1991. Food and shelter as determinants of food choice by an herbivorous marine amphipod. Ecology 72:1286-1298.

Duffy, J. E., and M. E. Hay. 1994. Herbivore resistance to seaweed chemical defense: the roles of mobility and predator risk. Ecology 75:1304-1319.

Gessner, F. 1970. Temperature: plants. Pages 363-406 in O. Kinne, editor. Marine ecology. Volume 1, part 1. Wiley, New York, New York, USA.

Hawkins, S. J., and R. G. Hartnoll. 1983. Grazing of intertidal algae by marine invertebrates. Oceanography and Marine Biology Annual Review 21:195-282.

Hay, M. E. 1981. The functional morphology of turf forming seaweeds: persistence in stressful marine habitats. Ecology 62:739-750.

2. 1986. Associational plant defenses and the maintenance of species diversity: turning competitors into accomplices. American Naturalist 128:617-641.

. 1992. The role of seaweed chemical defenses in the evolution of feeding specialization and in the mediation of complex interactions. Pages 93-118 in V. J. Paul, editor. Ecological roles of marine natural products. Cornell University Press, Ithaca, New York, USA.

Hay, M. E., J. E. Duffy, and W. Fenical. 1990. Host-plant specialization decreases predation on a marine amphipod: an herbivore in plant's clothing. Ecology 71:733-743.

Hay, M. E., J. E. Duffy, C. A. Pfister, and W. Fenical. 1987a. Chemical defense against different marine herbivores: are amphipods insect equivalents? Ecology 68:1567-1580.

Hay, M. E., and W. Fenical. 1988. Marine plant-herbivore interactions: the ecology of chemical defense. Annual Review of Ecology and Systematics 19:111-145.

Hay, M. E., W. Fenical, and K. Gustafson. 1987b. Chemical defense against diverse coral-reef herbivores. Ecology 68: 1581-1591.

Hay, M. E., Q. E. Kappel, and W. Fenical. 1994. Synergisms in plant defenses against herbivores: interactions of chemistry, calcification, and plant quality. Ecology 75:17141726.

Hay, M. E., R. R. Lee Jr., and R. A. Guieb. 1986. Food preference and chemotaxis in the sea urchin Arbacia punctulata (Lamarck) Philippi. Journal of Experimental Marine Biology and Ecology 96:147-153.

Hay, M. E., P. E. Renaud, and W. Fenical. 1988. Large mobile versus small sedentary herbivores and their resistance to seaweed chemical defenses. Oecologia 75:246-252.

Hay, M. E., and P. D. Steinberg. 1992. The chemical ecology of plant-herbivore interactions in marine versus terrestrial communities. Pages 371-413 in G. A. Rosenthal and M. R. Berenbaum, editors. Herbivores: their interactions with secondary plant metabolites. Volume II: Evolutionary and ecological processes. Academic Press, New York, New York, USA.

Hay, M. E., and J. P. Sutherland. 1988. The ecology of rubble structures of the South Atlantic Bight: a community profile. U.S. Fish and Wildlife Service Biological Report 85 (7.10). Hay, M. E., and P. R. Taylor. 1985. Competition between herbivorous fishes and urchins on Caribbean reefs. Oecologia 65:591-598.

Hirschfeld, D. R., W. Fenical, G. H. Y. Lin, R. M. Wing, and P. C. Radlick. 1973. Pachydictyol A, a unique diterpene 
alcohol from the brown seaweed Pachydictyon coriaceum. Journal of the American Chemical Society 95:40-49.

Horn, M. H. 1989. Biology of marine herbivorous fishes. Oceanography and Marine Biology Annual Review 27: $167-272$.

Janzen, D. H. 1979. New horizons in the biology of plant defenses. Pages 331-350 in G. A. Rosenthal and D. H. Janzen, editors. Herbivores: their interactions with secondary plant metabolites. Academic Press, New York, New York, USA.

Kareiva, P. 1994. Higher order interactions as a foil to reductionist ecology. Ecology 75:1527-1528.

Koehl, M. A. R., and S. A. Wainwright. 1977. Mechanical adaptations of a giant kelp. Limnology and Oceanography 22:1067-1071.

Lawrence, J. M. 1975. On the relationships between marine plants and sea urchins. Oceanography and Marine Biology Annual Review 13:213-286.

Levitan, D. R. 1989. Density-dependent size regulation in Diadema antillarum: Effects on fecundity and survivorship. Ecology 70:1414-1424.

Littler, M. M. 1979. The effects of bottle volume, thallus weight, oxygen saturation levels, and water movement on apparent photosynthetic rates in marine algae. Aquatic Botany $7: 21-34$.

Lubchenco, J., and S. D. Gaines. 1981. A unified approach to marine plant-herbivore interactions. I. Populations and communities. Annual Review of Ecology and Systematics 12:405-437.

McEnroe, F. J., K. J. Robertson, and W. Fenical. 1977. Diterpenoid synthesis in brown seaweeds of the family Dictyotaceae. Pages 179-189 in D. J. Faulkner and W. H. Fenical, editors. Marine natural products chemistry. Plenum, New York, New York, USA.

Morrison, D. 1988. Comparing fish and urchin grazing in shallow and deeper coral reef algal communities. Ecology 69:1367-1382.

Paul, V. J. 1992. Seaweed chemical defenses on coral reefs. Pages 24-50 in V. J. Paul, editor. Ecological roles of marine natural products. Cornell University Press, Ithaca, New York, USA.

Peterson, C. H., and R. Black. 1988. Density-dependent mortality caused by physical stress interacting with biotic history. American Naturalist 131:257-270.

Peterson, C. H., and P. E. Renaud. 1989. Analysis of feeding preference experiments. Oecologia 80:82-86.

Pfister, C. A., and M. E. Hay. 1988. Associational plant refuges: convergent patterns in marine and terrestrial communities result from differing mechanisms. Oecologia 77: $118-129$.
Renaud, P. E., M. E. Hay, and T. M. Schmitt. 1990. Interactions of plant stress and herbivory: intraspecific variation in the susceptibility of a palatable versus an unpalatable seaweed to sea urchin grazing. Oecologia 82:217-226.

Rice, W. R., and S. D. Gaines. 1994. 'Heads I win, tails you lose': testing directional alternative hypotheses in ecological and evolutionary research. Trends in Ecology and Evolution 9:235-237.

Rhoades, D. F. 1985. Offensive-defensive interactions between insects and plants: their relevance in herbivore population dynamics and ecological theory. American Naturalist 125:205-238.

Robertson, D. R. 1982. Fish feces as fish food on a Pacific coral reef. Marine Ecology Progress Series 7:253-265.

Rowley, R. J. 1990. Newly settled sea urchins in a kelp bed and urchin barren ground: a comparison of growth and mortality. Marine Ecology Progress Series 62:229-240.

Schmitt, R. J. 1987. Indirect interactions between prey: apparent competition, predator aggregation, and habitat segregation. Ecology 68:1887-1897.

Stachowicz, J. J., and M. E. Hay 1996. Facultative mutualism between an herbivorous crab and its coralline algal host. Oecologia 105:377-387.

Steinberg, P. D. 1992. Geographic variation in the interaction between marine herbivores and brown algal secondary metabolites. Pages 51-92 in V. J. Paul, editor. Ecological roles of marine natural products. Cornell University Press, Ithaca, New York, USA.

1994. Lack of short-term induction of phlorotannins in the Australian brown algae Ecklonia radiata and Sargassum vestitum. Marine Ecology Progress Series 112:129133.

. 1995. Interaction between the canopy dwelling echinoid Holopneustes purpurescens and its host kelp Ecklonia radiata. Marine Ecology Progress Series 127:169-181.

Tsuda, R. T., and P. G. Bryan. 1973. Food preference of juvenile Siganus rostratus and S. spinus in Guam. Copeia 1973:604-606.

Van Alstyne, K. L. 1988. Herbivore grazing increases polyphenolic defenses in the intertidal brown alga Fucus distichus. Ecology 69:655-663.

White, T. C. R. 1984. The abundance of invertebrate herbivores in relation to the availability of nitrogen in stressed food plants. Oecologia 63:90-105.

Wootton, J. T. 1994. Putting the pieces together: testing the independence of interactions among organisms. Ecology 75: $1544-1551$.

Yates, J. L., and P. Peckol. 1993. Effects of nutrient availability and herbivory on polyphenolics in the seaweed $\mathrm{Fu}$ cus vesiculosus. Ecology 74:1757-1766. 